\title{
Correlation Analysis of the Indicators of Asset Management and Profitability
}

\author{
Silviu Carstina, Marian Siminica, Daniel Cîrciumaru, Anca Tănasie ${ }^{1}$
}

\begin{abstract}
:
Optimum Asset Management has been and is today a concern in the management of an enterprise, its effects being felt as indicators of results. The way in which asset management results indicators and thus affect the profitability of an enterprise have proved it by conducting a case study in the companies in the food industry Spania.Modul Rioja region where asset management results indicators and thus influence the profitability of businesses I demonstrated by conducting a case study in the companies in the food industry of the region Rioja Spain.

The program is used to establish the correlation SPSS while watching the correlation and its economic-mathematical modeling and using SABI research platform, the platform belonging to the University of Rioja, Spain. We chose the food industry because of this industry perishable products requires proper management as the company's assets.
\end{abstract}

Key Words: rentability, ratio assets, correlation, research platform

Jel Classification: $G 1, M 1, C 1$

\footnotetext{
${ }^{1}$ University of Craiova, Faculty of Economics and Business Administration
} 


\section{Introduction}

This article forms part of his doctoral thesis which has the title "Analysis of asset management and its implications on profitability, lead author of the paper that this research Apart.

A competitive economy is an economy that has the structure of economic entities performing entities ever to face any challenge. Speaking of performance we report immediately to the two concepts that define performance: efficiency and effectiveness (Hanias et al., 2007).

Between the two concepts are closely interdependent, meaning that an efficient undertaking without being effective will not have a very long period of existence, and an effective enterprise efficiency but without obtaining results automatically lead to unfavorable economic entity.

Efficiency is the key word of this research, and it represents the ratio of a company effort and result from that effort, or rather how they are used assets and equity values taking into consideration the fundamentals of the economy (Thalassinos et al., 2012; Thalassinos, 2014: Thalassinos et al., 2014; Thalassinos and Liapis 2014; Thalassinos et al., 2015).

The authors Gheorghe Zaman and Marinela Geamănu efficiency as a specific element of several areas (economic, social, technological, ecological), was found both in practical activities of man and the concerns theoretical and methodological, but in economics it is defined as "an area of prime importance for studying the economic phenomena and processes, in terms of ratio, correlation, comparison of costs, efforts, consumption of resources, on the one hand, and the results, effects, production carried on by Moreover, expressed in physical units and value "2.

Another definition of efficiency is found to author Lucian Buse namely: "the term efficiency know more accepted in the economic literature, some authors finding that an activity is effective when it reaches the desired goal with minimal effort" ${ }^{\prime 3}$.

So based on this concept to determine and analyze a number of indicators that define how they have been used assets of enterprises and the results from them, the industrial sector is that of food production, the companies being and having the object of activity in Spain, Rioja region. Based on the results obtained from the accounting documents submitted by them we performed an analysis of the intensity and type of correlation between two categories of indicators: management and profitability, but both categories belonging efficiency.

${ }^{2}$ Gheorghe Zaman, Marinela Geamanu, Eficiența economică, Ed. Fundației Romania de mîine, București, 2006, pag. 14

${ }^{3}$ Bușe Lucian, Analiză economico-financiară, Ed. Economică, București, 2005, p. 132 
An item of infrastructure increasingly common in European universities is given to the use of research platforms and not just statistical programs. Moreover there is an increasingly replacement research programs with these assay platforms, the latter having incorporate arrangements and analysis of statistical and mathematical techniques.

Efficiency thus seen from different levels, interrelated this is reflected through indicators expressed in various forms but essentially they all reflecting how they are managed and used assets of an undertaking.

\section{Concepts and terms used}

To achieve this works in addition to the term of effectiveness of this in the introduction and presentation of the indicators used is needed both in terms of transmitted information and the way its calculation.

Defining concepts was conducted using both its views presented by specialists nationally and especially internationally.

Indicators MIRRORS profitability at a company level are reflected both in relative and absolute form. Of absolute indicators correlation analysis we used: operating result, financial result, total result, EBITDA and EBIT; and the use of relative indicators are: economic rate of return of capital, financial rate of return, rate of return on sales and expenditure or consumption.

Both the absolute and relative indicators I use presented through an array of profitability indicators as follows:

Table 1. Absolute profitability indicators use

\begin{tabular}{|l|l|l|}
\hline \multicolumn{1}{|c|}{ income } & \multicolumn{1}{c|}{ expenditure } & \multicolumn{1}{c|}{ result } \\
\hline+ operating income & - operating expanses & Operating result $(\mathrm{Pe})$ \\
\hline+ financial income & - financial expanses & Financial result $(\mathrm{Pf})$ \\
\hline+ total income & - total expanses & Total result $(\mathrm{Pt})$ \\
\hline+ total result & + interest expense & EBIT \\
\hline+ EBIT & + Amortisation & EBITDA \\
\hline
\end{tabular}

Source: Table made by the authors

As meanings operating income is the result of an undertaking to the work carried out on a certain time, which is often confused with the potential cash flow or as it is also recognized as the gross operating surplus. 
6

The financial result is actually the difference between revenues and financial cehltuielile $d$ ela enterprise level and is mostly due to loans made by the company to finance both current needs and investments.

Belly total result is the difference between total income and expenses of an enterprise, which is a result of the country affected by fiscal policy, being based reporting in determining the entity income tax due to the state budget.

EBIT and EBITDA are two indicators belonging to Anglo-Saxon system and less French system basically their relationship finally being adapted nevertheless substantial adjustments resulting from this all-surpassing being so representative.

Expressions profitability using relative indicators calculated from the overall efficiency equation, namely by comparing the actual effect achieved with the effort made by the company to achieve that effect.

Indicators of profitability it is also reflected by using the following table:

Table 2. Indicators of profitability of an enterprise

\begin{tabular}{|c|c|c|}
\hline effect indicators & indicators of effort & profitability \\
\hline Gross profit & permanent capital & Return on economic equity $(\mathrm{Re})$ \\
\hline Net profit & Personal capital & Financial rate of return (Rf) \\
\hline Operating result & \multirow{2}{*}{ Expenses turnover } & \multirow{2}{*}{ Return on costs (Rrc) } \\
\hline Profit for turnover & & \\
\hline Operating profit & \multirow[b]{2}{*}{ Turnover } & \multirow{2}{*}{$\begin{array}{l}\text { Return on sales / commercial } \\
\text { (Rcom) }\end{array}$} \\
\hline Profit for turnover & & \\
\hline
\end{tabular}

Source: Table made by the authors

Using therefore these indicators and also causing the indicators of management of the assets given the speed of rotation of their measured as indicators of results and that asset we performed an analysis of the correlation, watching how this asset management in an enterprise influence the profitability.

\section{Research methodology}

Based on the profitability indicators such as absolute and relative we determined the indicators reflecting asset management companies analyzed. 
First we thought impedios after determining the necessary indicators presented the evolution of profitability of companies from Spain - Rioja region. As a sector we chose food. considering the theme of the research work we considered the most representative branch in terms of highly perishable products. So in this industry since the speed is higher, exactly how much faster current creates value both company profitability should at least theoretically be influenced positively.

At the level of companies in the Spanish region of Rioja undercurrents in 2013, the last year surprised the analysis, around 300 companies with activities in which belonged food industry, but we made a selection among them, the selection criterion is given by the indicator turnover. So after I decided to look at companies with turnover of more than EUR 10,000, we finally decided on a number of 198 companies.

The period under review we decided in November due to the large number of variables to be 2012 - 2013, although the average level of profitability analysis went on peroada specific data from 2010 to 2013.

Indicators renatbilitate both the absolute and relative who are currently under a table passed as an annex (Annex 1) for more research in this paper, which is of a large size.

I realized correlation analysis using Pearson index, the SPSS statistical program used. Modeling level of correlation being made but with more research platform SABI ajutroul Neo paltform found in the University of Rioja, Faculty of Economics and manage their businesses.

\section{Case study}

The impact of the financial crisis, however, was different from one country to another, from one industry to another, from one firm to another, even if we speak the same field.

One of the explanations people's specialty would be that a small firms with a level of technology lowest presents greater flexibility and therefore increased capacity to adapt to the changing environment in which they operate, and changes that occur the market from customers, suppliers, etc. As a company with a higher level of technology adapts to these changes but in a larger time interval and of course incurring higher costs.

For this study we considered the companies Rioja Spain, belonging to food industry companies analyzed period regarding the profitability trend $2010-2013$, correlation analysis, they are only the last two years 2012-2013. 
8

To analyze profitability at companies of Rioja we used the electronic platform SABI University of Rioja, Faculty of Economics. In this platform with a user and password data I entered the business section where, depending on the scope of activity and the region over the undertaking, we selected those businesses related to the food industry in Rioja.

The individual companies have selected balance sheet and profit and loss account, financial and accounting documents with which we calculated and analyzed a number of indicators of profitability.

For more rapid absolute indicators of profitability we determined for each indicator an average Rioja food industry. The mean results for each indicator are shown in table immediately below:

Table 3. Media absolute indicators of profitability in the food industry Rioja - Spain for the period $2010-2013$

\begin{tabular}{|c|c|c|c|c|r|}
\hline Media & Pe & Pf & Rt & EBIT & EBITDA \\
\hline $\mathbf{2 0 1 0}$ & 547.653 & -8.660 & 538.994 & 547.653 & 838.877 \\
\hline $\mathbf{2 0 1 1}$ & 547.752 & -8.650 & 539.102 & 547.752 & 838.975 \\
\hline $\mathbf{2 0 1 2}$ & 548.123 & -8.649 & 539.474 & 548.123 & 839.382 \\
\hline & & - & & & \\
$\mathbf{2 0 1 3}$ & 555.495 & 13.616 & 541.879 & 555.495 & 847.725 \\
\hline
\end{tabular}

Source: Table created by processing data from Annex 1

Considering the average values reflected in the above table so we can achieve a profitability analysis of the evolution in terms of absolute indicators.

Thus, in the operating activity is an increase in average operating result for the entire period. This increase can be explained by the fact that Rioja to the food industry has increased the number of enterprises operating profit above the average for the activity determined in each individual year.

The same evolution is observed and if total earnings from the companies in the food industry riojene. It seems that from year to year has recorded a growing number of enterprises that have achieved above average results for each individual year.

Relating simultaneously to two indicators EBIT and EBITDA in addition to, and if their situation is similar to what we had on profitability indicators earlier, here we can say that there is a difference in level considerably between the two indicators. This difference can be explained in terms of the level of depreciation. Basically being production-oriented companies is clear that we are talking here of a high tech level. 
In determining the level and also to achieve a profitability analysis in terms of relative indicators we have kept the same procedure as in absolute indicators.

And if these indicators, to carry out an analysis with ease, without having to approach individual companies, we determined the average level in the food industry in Rioja - Spain.

Table 4. Average relative indicators of profitability in the food industry in Rioja the period 2010 - 2013

\begin{tabular}{|c|c|c|c|c|}
\hline Media & Re & Rf & Rrc & Rv \\
\hline $\mathbf{2 0 1 0}$ & $6,01 \%$ & $51,75 \%$ & $6,59 \%$ & $5,84 \%$ \\
\hline $\mathbf{2 0 1 1}$ & $6,08 \%$ & $51,74 \%$ & $6,64 \%$ & $5,89 \%$ \\
\hline $\mathbf{2 0 1 2}$ & $6,50 \%$ & $52,34 \%$ & $6,70 \%$ & $5,94 \%$ \\
\hline $\mathbf{2 0 1 3}$ & $6,41 \%$ & $22,69 \%$ & $6,72 \%$ & $5,95 \%$ \\
\hline
\end{tabular}

Source: Table created by processing data from Annex 1

In 2013 there was a slight decline in the indicator compared to 2012. This decline could be justified by reference to data from us and Table 4.2 where the average total profit is increasing by an increase in the companies the average value of total assets.

The rate of return on equity is a decrease of the mean at a very high level in 2013 compared to other years. This, as I considered the data from the balance sheet and income statement of profit can be explained by a decrease in average net profits of the food industry in a much faster rate than the average equity.

In terms of efficiency in the use of spending is an increase in average spending rate of return, this meaning that to produce the same results companies have succeeded in reducing the level of expenditure from one year to another.

Return on sales records from year to year a growing medium, this meaning that the level of companies in the food industry of Rioja increased during this time profit share from the total turnover expenses.

Correlation analysis between micro and macro certain indicator is one way that highlighted the links that exist between these indicators and how they influence. Also correlation analysis is a first step to achieve an economic and mathematical model, the intensity of the link between these indicators which justifies the importance of its creation.

At the level of companies in the food industry in Rioja - Spain correlation analysis of indicators of asset management and profitability indicators is performed using SPSS statistical software, the index used is the index Pearson. 
At the company level Rioja - Spain, have been complied same procedures as for companies from Dolj, the correlation established between indicator is reflected in the following table:

\begin{tabular}{|c|c|c|c|c|c|c|c|c|c|c|}
\hline \multicolumn{11}{|c|}{ Correlations } \\
\hline & & $\mathrm{Pe}$ & $\mathrm{Pf}$ & Rt & EBIT & $\begin{array}{c}\text { EBITD } \\
\text { A }\end{array}$ & $\mathrm{Re}$ & $\mathrm{Rf}$ & Rrc & $\mathrm{Rv}$ \\
\hline \multirow[t]{3}{*}{ CA/AC } & $\begin{array}{l}\text { Pearson } \\
\text { Correlation }\end{array}$ &,- 120 &,$- 241^{* * *}$ &,- 148 &,- 120 &,- 138 &,- 169 &, 005 & $\begin{array}{c}- \\
, 362^{* * *}\end{array}$ & ,280** \\
\hline & Sig. (2-tailed) & ,201 & ,010 &, 114 & 201 & ,141 &, 071 & ,959 & ,000 & ,002 \\
\hline & $\mathrm{N}$ & 115 & 115 & 115 & 115 & 115 & 115 & 115 & 115 & 115 \\
\hline \multirow[t]{3}{*}{ CA/At } & $\begin{array}{l}\text { Pearson } \\
\text { Correlation }\end{array}$ &,- 084 &,- 126 &,- 098 &,- 084 &,- 090 &,- 044 &, $733^{* *}$ & ${ }^{-}-5^{* *}$ &,$- 185^{*}$ \\
\hline & Sig. (2-tailed) & ,370 & ,180 & ,298 & ,370 & ,341 & ,642 & ,000 & ,008 & ,047 \\
\hline & N & 115 & 115 & 115 & 115 & 115 & 115 & 115 & 115 & 115 \\
\hline \multirow[t]{3}{*}{$\mathrm{Pe} / \mathrm{AC}$} & \begin{tabular}{|l|} 
Pearson \\
Correlation \\
\end{tabular} &, $750^{* * *}$ &, $291^{* * *}$ &, $748^{* * *}$ &, $750^{* * *}$ &, $647^{* *}$ &, $941^{* * *}$ & ,196* &, $768^{* *}$ &, $866^{* * *}$ \\
\hline & Sig. (2-tailed) &, 000 & ,002 & ,000 & ,000 & ,000 & ,000 & ,036 & , 000 & , 000 \\
\hline & $\mathrm{N}$ & 115 & 115 & 115 & 115 & 115 & 115 & 115 & 115 & 115 \\
\hline \multirow[t]{3}{*}{$\mathrm{Pe} / \mathrm{AT}$} & $\begin{array}{l}\text { Pearson } \\
\text { Correlation }\end{array}$ &, $718^{* * *}$ &, $329^{* *}$ &, $723^{* * *}$ &, $718^{* *}$ &, $596^{* *}$ &, $974^{* *}$ &, $245^{* *}$ &, $799^{* *}$ &, $874^{* *}$ \\
\hline & Sig. (2-tailed) & ,000 & ,000 & ,000 & ,000 & ,000 & ,000 & ,008 & , 000 & ,000 \\
\hline & $\mathrm{N}$ & 115 & 115 & 115 & 115 & 115 & 115 & 115 & 115 & 115 \\
\hline \multirow[t]{3}{*}{$\mathrm{AC} / \mathrm{CA}$} & $\begin{array}{l}\text { Pearson } \\
\text { Correlation }\end{array}$ & ,149 & ,399** & ,199* & , 149 & ,138 &, 170 & ,034 &, $520^{* *}$ &, $401^{* * *}$ \\
\hline & Sig. (2-tailed) &, 111 &, 000 & ,033 & ,111 & ,141 & ,069 & ,720 & , 000 & ,000 \\
\hline & $\mathrm{N}$ & 115 & 115 & 115 & 115 & 115 & 115 & 115 & 115 & 115 \\
\hline \multirow[t]{3}{*}{$\mathrm{AC} / \mathrm{Ve}$} & $\begin{array}{l}\text { Pearson } \\
\text { Correlation }\end{array}$ & , 150 & $400^{* * *}$ & ,200* & , 150 & ,139 &, 170 & ,033 &, $519^{* *}$ & ,400** \\
\hline & Sig. (2-tailed) & ,110 &, 000 & ,032 & ,110 & ,139 & ,069 & ,725 & ,000 & ,000 \\
\hline & $\mathrm{N}$ & 115 & 115 & 115 & 115 & 115 & 115 & 115 & 115 & 115 \\
\hline \multirow[t]{3}{*}{$\mathrm{Ac} / \mathrm{Pe}$} & \begin{tabular}{|l|} 
Pearson \\
Correlation \\
\end{tabular} &,- 084 &,- 027 &,- 083 &,- 084 &,- 073 &,- 159 & ,157 &,$- 213^{*}$ &,- 158 \\
\hline & Sig. (2-tailed) &, 373 &, 776 & ,379 &, 373 & ,437 & ,090 & ,094 & 022 & 092 \\
\hline & $\mathrm{N}$ & 115 & 115 & 115 & 115 & 115 & 115 & 115 & 115 & 115 \\
\hline \multirow[t]{3}{*}{ PB/At } & \begin{tabular}{|l} 
Pearson \\
Correlation
\end{tabular} &, $736^{* * *}$ & $484^{* * *}$ &, $763^{* * *}$ &, $736^{* * *}$ &, $626^{* * *}$ & $1,000^{* * *}$ &, $273^{* * *}$ &, $837^{* *}$ &, $898^{* * *}$ \\
\hline & Sig. (2-tailed) &, 000 & , 000 & , 000 & ,000 & ,000 & ,000 &, 003 &, 000 & , 000 \\
\hline & $\mathrm{N}$ & 115 & 115 & 115 & 115 & 115 & 115 & 115 & 115 & 115 \\
\hline \multirow[t]{3}{*}{ EBIT/AC } & $\begin{array}{l}\text { Pearson } \\
\text { Correlation }\end{array}$ &, $750^{* * *}$ & $291^{* *}$ &, $748^{* * *}$ &, $750^{* * *}$ &, $647^{* *}$ &, $941^{* * *}$ & ,196* &, $768^{* *}$ &, $866^{* *}$ \\
\hline & Sig. (2-tailed) &, 000 &, 002 & ,000 & ,000 & ,000 & ,000 & ,036 &, 000 & , 000 \\
\hline & $\mathrm{N}$ & 115 & 115 & 115 & 115 & 115 & 115 & 115 & 115 & 115 \\
\hline
\end{tabular}




\begin{tabular}{|l|l|c|c|c|c|c|c|c|c|c|}
\hline EBIT/AT & $\begin{array}{l}\text { Pearson } \\
\text { Correlation }\end{array}$ &, $614^{* *}$ &, $301^{* *}$ &, $622^{* *}$ &, $614^{* *}$ &, $552^{* *}$ &, $884^{* *}$ &, $504^{* *}$ &, $705^{* *}$ &, $778^{* *}$ \\
\cline { 2 - 11 } & Sig. (2-tailed) &, 000 &, 001 &, 000 &, 000 &, 000 &, 000 &, 000 &, 000 &, 000 \\
\cline { 2 - 10 } & $\mathrm{N}$ & 115 & 115 & 115 & 115 & 115 & 115 & 115 & 115 & 115 \\
\hline
\end{tabular}

Source: Table obtained using SPSS

From the resulting data we can say that the level of companies in the food industry in Rioja there are strong correlations between indicators and significant management and the profitability of assets.

In light of current assets rotational speed of the resulting data that is found in the industry, the correlation between this indicator and other indicators of return is one insignificant correlation values results being very close to the value 0 .

In terms of speed of rotation of total assets but there is a significant correlation with financial rate of return, this index has the value 0.733 .

A special case is found indicators of activity (management) of the assets created from the result for the operating business and in terms of gross operating surplus. If these indicators is a strong correlation with the company's profitability in terms of both absolute indicators: operating result, total result, EBIT and EBITDA; and in terms of relative indicators: economic rate of return, rate of return on resources consumed and the rate of return on sales.

Regarding the financial rate of return we can only say that if the indicator EBIT / AT there is a significant correlation, the resulting value being 0.504 .

Given the results obtained in most indicators expresses how they were managed assets regardless of their form, we can say that there is a strong link between them and the profitability achieved by the company. What was natural and logical as the company sees better manage these assets much higher resulting profitability, evidenced also by using the direct links established between the indicators used in the analysis.

After those steps we made in the companies in the food industry in Rioja - Spain, econometric model correlations that exist between indicators and the management of the assets of profitability.

A first econometric model was established between the economic profitability as the dependent variable and the speed of rotation of net assets as independent variables, variables results are presented in Annex 2 of the paper.

After analyzing the correlation between asset management indicator, the speed of rotation of assets, and economic profitability established a strong inverse correlation, the correlation coefficient of -0.793 being. 
Econometric model of these correlations using SABI platform yielded the following regression equations:

$$
y=-0,582 x+2,21
$$

At the end of modeling the relationships we conducted a graph of the equation is a graph illustrating the concentration points around the equation:

Chart 1.Graph the regression model

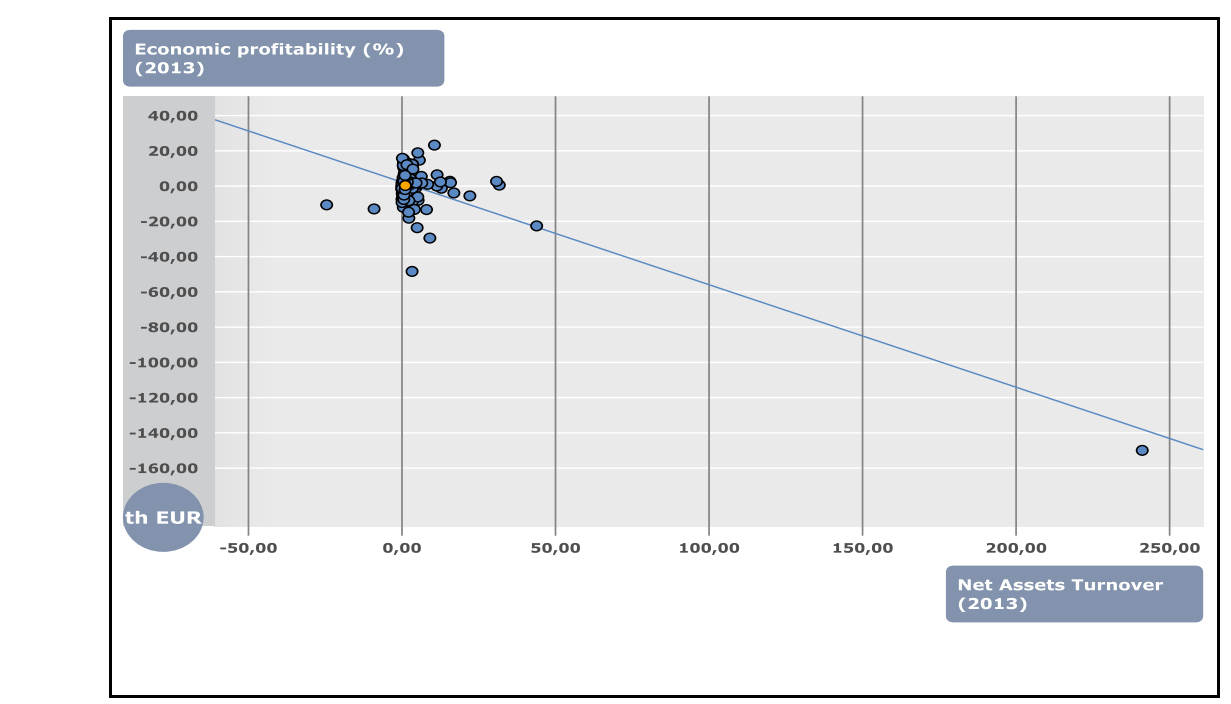

Source: SABI platform

The chart above that as the rotational speed increases economic profitability tends to fall. Concentration points on the graph shows that most of the values used in the analysis concentrated and tend to be closer to the value 0 .

\section{Conclusions}

Analysis of asset management was pursued both by the efficiency indicators (rotation speed, the duration in days of revolutions, operating profit of 100 lei total assets, operating income of 100 lei relative assets) and in terms of the overall effect of the way they are used inside the enterprise, effects resulting from the evaluation process.

The way and intensity of links between asset management in terms of efficiency indicators and the profitability of the enterprise were pursued through programs and using statistical and mathematical models created factorial analysis.

At the company level Rioja - Spain on the level of operating activity is an increase in average operating result, while at financial activity level decrease. Basically 
outcome of firms in this region is due in particular operating activity, as is natural, and no financial activity. The financial activity we can say that companies have resorted to various forms of borrowing, either short term or long term, for financing activities or investments.

Indicators profitability reflects also of the entire analyzed period a favorable situation. Return on average economic growth reflects the overall efficiency of the business firms in the food processing sector, the return on the costs and strengthening sales through their level further the arguments.

After reflecting developments in corporate profitability levels in the food industry by using SPSS - site we conducted an analysis of the correlation between indicators of profitability and the management of the assets. Correlation analysis was performed using Pearson correlation index.

Following this analysis year found that there is a strong correlation between the speed of rotation of assets and the level of profitability achieved, the food industry is one of the industries that confirm this in terms of results.

\section{References}

Andrei Tudorel, Stancu Stelian, Iacob Andreea Iluzia, Tuşa Erika, Introducere în econometrie utilizând Eviews, Ed. Economică, București, 2008

Antonio Partal Urena, Fernando Moreno Bonilla, Manuel Cano Rodriguez și Pilar Gomez Fernandez-Aguado, Direccion financiera de la empresa, Ediciones Piramide, Madrid, 2012

Bușe Lucian, Analiză economico-financiară, Ed. Economică, București, 2005

Bușe Lucian, Carstina Silviu-Valentin, Profitability and risk analysis in the metallurgical industry leading companies in Romania, Analele Unievrsităţii din Craiova, 2012, vol. III

Gheorghe Zaman, Marinela Geamanu, Eficiența economică, Ed. Fundației Romania de mîine, București, 2006

Hanias, P.M., Curtis, G.P. and Thalassinos, E.J. (2007). Non-linear dynamics and chaos: The case of the price indicator at the Athens Stock Exchange. International Research Journal of Finance and Economics, 11(1), 154-163.

Juan F. Perez-Carballo Veiga, Diagnostico economico-financiero de la empresa, ESIC, Madrid, 2010

***https://sabi.bvdinfo.com/version-2015330/home.serv?product=SabiNeo

Thalassinos, I.E., Ugurlu, E. and Muratoglu, Y. (2012). Income Inequality and Inflation in the EU. European Research Studies Journal, 15(1), 127-140.

Thalassinos, I.E., Stamatopoulos, D.T. and Thalassinos, E.P. (2015). The European Sovereign Debt Crisis and the Role of Credit Swaps. Chapter book in The WSPC Handbook of Futures Markets (eds) W. T. Ziemba and A.G. Malliaris, in memory of Late Milton Miller (Nobel 1990) World Scientific Handbook in Financial Economic Series Vol. 5, Chapter 20.

Thalassinos, E.P. (2014). Credit Default Swaps and Sovereign Debt in Eurozone. Chapter book in Risk Management: Strategies for Economic Development and Challenges in 
the Financial System,(eds), D. Milos Sprcic, Nova Publishers, 255-278, ISBN: 978163321539-9; 978-163321496-5.

Thalassinos, I.E., Liapis, K. and Thalassinos, E.J. (2014). The role of the rating companies in the recent financial crisis in the Balkan and black sea area. Chapter book in Economic Crisis in Europe and the Balkans, 79-115, Contributions to Economics, Springer International Publishing, DOI: 10.1007/978-3-319-00494-5-6. $11+1+1$

Thalassinos I.E. and Liapis K. (2014). Segmental financial reporting and the internationalization of the banking sector. Chapter book in, Risk Management: Strategies for Economic Development and Challenges in the Financial System,(eds), D. Milos Sprcic, Nova Publishers, 221-255, ISBN: 978-163321539-9; 978$\underline{163321496-5 .}$

\section{Annex 1}

The profitability of firms in terms of absolute indicators:

\begin{tabular}{|c|c|c|c|c|c|c|}
\hline year & Pe & Pf & Rt & EBIT & EBITDA & company \\
\hline 2010 & 11.835 & -925 & 10.910 & 11.835 & 15.286 & \multirow{4}{*}{$\begin{array}{l}\text { CONSERVAS EL } \\
\text { CIDACOS SA }\end{array}$} \\
\hline 2011 & 14.693 & -648 & 14.045 & 14.693 & 18.114 & \\
\hline 2012 & 11.618 & -1.433 & 10.185 & 11.618 & 15.349 & \\
\hline 2013 & 17.795 & -535 & 17.260 & 17.795 & 21.524 & \\
\hline 2010 & 6.654 & -432 & 6.222 & 6.654 & 8.323 & \multirow{4}{*}{$\begin{array}{c}\text { PALACIOS } \\
\text { ALIMENTACION SAU } \\
\text { (EXTINGUA) }\end{array}$} \\
\hline 2011 & 17.415 & -398 & 17.017 & 17.415 & 20.136 & \\
\hline 2012 & 10.165 & 202 & 10.367 & 10.165 & 12.514 & \\
\hline 2013 & 9.688 & 938 & 10.626 & 9.688 & 11.567 & \\
\hline 2010 & 106.087 & -18.544 & 87.543 & 106.087 & 867.358 & \multirow{4}{*}{$\begin{array}{c}\text { ALEJANDRO MIGUEL } \\
\text { SL }\end{array}$} \\
\hline 2011 & 319.871 & -162.594 & 157.277 & 319.871 & 1.109 .313 & \\
\hline 2012 & 375.773 & -96.521 & 279.252 & 375.773 & 1.521 .845 & \\
\hline 2013 & 689.661 & -128.399 & 561.262 & 689.661 & 1.847 .251 & \\
\hline 2010 & 56.704 & -165.675 & -108.971 & 56.704 & 387.735 & \multirow{4}{*}{$\begin{array}{l}\text { HARINERA } \\
\text { RIOJANA }\end{array}$} \\
\hline 2011 & -184.722 & -315.625 & -500.347 & -184.722 & 115.399 & \\
\hline 2012 & 566.679 & -377.879 & 188.800 & 566.679 & 860.815 & \\
\hline 2013 & 629.370 & -354.011 & 275.359 & 629.370 & 921.576 & \\
\hline 2010 & 1.621 .165 & -21.994 & 1.599 .171 & 1.621 .165 & 2.069 .595 & \multirow{4}{*}{ ARLUY SL } \\
\hline 2011 & 1.520 .620 & 54.638 & 1.575 .258 & 1.520 .620 & 2.202 .702 & \\
\hline 2012 & 1.455 .351 & 54.686 & 1.510 .037 & 1.455 .351 & 2.154 .533 & \\
\hline 2013 & 1.571 .414 & -55.226 & 1.516 .188 & 1.571 .414 & 2.604 .663 & \\
\hline 2010 & 185.646 & -74.807 & 110.839 & 185.646 & 426.633 & \multirow{4}{*}{$\begin{array}{l}\text { ELABORADOS } \\
\text { NATURALES DE LA } \\
\text { RIBERA SL }\end{array}$} \\
\hline 2011 & 573.951 & -81.292 & 492.659 & 573.951 & 868.332 & \\
\hline 2012 & 833.957 & -113.800 & 720.157 & 833.957 & 1.190 .370 & \\
\hline 2013 & 247.058 & -69.018 & 178.040 & 247.058 & 647.129 & \\
\hline 2010 & 121.062 & -195.393 & -74.331 & 121.062 & 490.038 & \multirow{4}{*}{$\begin{array}{l}\text { CONSERVAS } \\
\text { FERBA SA }\end{array}$} \\
\hline 2011 & 345.170 & -187.701 & 157.469 & 345.170 & 678.630 & \\
\hline 2012 & 550.525 & -243.314 & 307.211 & 550.525 & 897.548 & \\
\hline 2013 & 1.219 .544 & -184.954 & 1.034 .590 & 1.219 .544 & 1.589 .270 & \\
\hline 2010 & 2.832 .737 & 434.710 & 3.267 .447 & 2.832 .737 & 3.291 .869 & \multirow{4}{*}{$\begin{array}{c}\text { CONSERVAS FRANCO } \\
\text { RIOJANA SOCIEDAD } \\
\text { ANONIMA }\end{array}$} \\
\hline 2011 & 2.596 .335 & -186.058 & 2.410 .277 & 2.596 .335 & 3.079 .437 & \\
\hline 2012 & 1.943 .360 & -126.721 & 1.816 .639 & 1.943 .360 & 2.375 .707 & \\
\hline 2013 & 1.772 .362 & -286.705 & 1.485 .657 & 1.772 .362 & 2.081 .613 & \\
\hline 2010 & 155.042 & -143.202 & 11.840 & 155.042 & 361.710 & \multirow{4}{*}{$\begin{array}{c}\text { ALBERTO DE MIGUEL } \\
\text { SA }\end{array}$} \\
\hline 2011 & 246.200 & -168.390 & 77.810 & 246.200 & 461.697 & \\
\hline 2012 & 247.729 & -184.003 & 63.726 & 247.729 & 465.777 & \\
\hline 2013 & 192.525 & -156.921 & 35.604 & 192.525 & 406.609 & \\
\hline 2010 & 360.778 & -41.789 & 318.989 & 360.778 & 500.928 & LA ALEGRIA RIOJANA \\
\hline
\end{tabular}




\begin{tabular}{|c|c|c|c|c|c|c|}
\hline 2011 & 346.406 & -15.421 & 330.985 & 346.406 & 495.464 & \\
\hline 2012 & 275.766 & -834 & 274.932 & 275.766 & 444.834 & \\
\hline 2013 & 385.385 & -4.501 & 380.884 & 385.385 & 591.495 & \\
\hline 2010 & 1.939 .881 & 129.623 & 2.069 .504 & 1.939 .881 & 2.429 .158 & \multirow{4}{*}{$\begin{array}{c}\text { RIOJANA DE GRASAS } \\
\text { SA }\end{array}$} \\
\hline 2011 & 2.321 .750 & 166.921 & 2.488 .671 & 2.321 .750 & 2.745 .492 & \\
\hline 2012 & 1.906 .075 & 150.809 & 2.056 .884 & 1.906 .075 & 2.265 .786 & \\
\hline 2013 & 1.216 .616 & 146.259 & 1.362 .875 & 1.216 .616 & 1.553 .872 & \\
\hline 2010 & 884.520 & 94.424 & 978.944 & 884.520 & 2.191 .841 & \multirow{4}{*}{$\begin{array}{l}\text { FONCASAL TRADING } \\
\text { SOCIEDAD LIMITADA }\end{array}$} \\
\hline 2011 & 1.205 .332 & -44.078 & 1.161 .254 & 1.205 .332 & 2.477 .963 & \\
\hline 2012 & 1.037 .494 & -153.473 & 884.021 & 1.037 .494 & 2.184 .992 & \\
\hline 2013 & -7.913 .192 & -470.906 & -8.384 .098 & -7.913 .192 & -6.615 .384 & \\
\hline 2010 & 1.060 .507 & 162.315 & 1.222 .822 & 1.060 .507 & 1.477 .722 & \multirow{4}{*}{$\begin{array}{l}\text { VINAGRERIAS } \\
\text { RIOJANAS SA }\end{array}$} \\
\hline 2011 & 366.069 & 168.679 & 534.748 & 366.069 & 742.893 & \\
\hline 2012 & 291.189 & 167.715 & 458.904 & 291.189 & 675.058 & \\
\hline 2013 & 442.646 & 549.935 & 992.581 & 442.646 & 787.070 & \\
\hline 2010 & 1.108 .074 & -60.745 & 1.047 .329 & 1.108 .074 & 1.306 .750 & \multirow{4}{*}{$\begin{array}{c}\text { COMERCIAL } \\
\text { RIOVERDE SOCIEDAD } \\
\text { ANONIMA }\end{array}$} \\
\hline 2011 & 832.677 & 4.981 & 837.658 & 832.677 & 1.030 .345 & \\
\hline 2012 & 882.538 & 130 & 882.668 & 882.538 & 1.044 .138 & \\
\hline 2013 & 738.151 & 5.209 & 743.360 & 738.151 & 887.209 & \\
\hline 2010 & 1.859 .916 & 323.641 & 2.183 .557 & 1.859 .916 & 2.093 .182 & \multirow{4}{*}{$\begin{array}{c}\text { EMBUTIDOS } \\
\text { ALEJANDRO SA }\end{array}$} \\
\hline 2011 & 1.996 .270 & -263.052 & 1.733 .218 & 1.996 .270 & 2.229 .817 & \\
\hline 2012 & 1.823 .850 & 196.459 & 2.020 .309 & 1.823 .850 & 2.067 .010 & \\
\hline 2013 & 2.106 .148 & 178.522 & 2.284 .670 & 2.106 .148 & 2.291 .888 & \\
\hline 2010 & 346 & -60 & 286 & 346 & 650 & \multirow{4}{*}{$\begin{array}{l}\text { GRANDERROBLE } \\
\text { DESSERTS SOCIEDAD } \\
\text { LIMITADA }\end{array}$} \\
\hline 2011 & 761 & -17 & 744 & 761 & 1.005 & \\
\hline 2012 & 644 & 7 & 651 & 644 & 967 & \\
\hline 2013 & -1.623 & -303 & -1.926 & -1.623 & -1.206 & \\
\hline 2010 & 449.159 & -95.867 & 353.292 & 449.159 & 730.756 & \multirow{4}{*}{$\begin{array}{c}\text { MATADERO JOSE } \\
\text { CALATAYUD E HIJOS } \\
\text { SA }\end{array}$} \\
\hline 2011 & 341.561 & -72.660 & 268.901 & 341.561 & 634.978 & \\
\hline 2012 & 104.025 & 41.666 & 145.691 & 104.025 & 393.253 & \\
\hline 2013 & 272.341 & 335.751 & 608.092 & 272.341 & 557.009 & \\
\hline 2010 & 544.011 & -88.269 & 455.742 & 544.011 & 812.413 & \multirow{4}{*}{$\begin{array}{c}\text { LACTEOS MARTINEZ } \\
\text { SL }\end{array}$} \\
\hline 2011 & 515.705 & -31.574 & 484.131 & 515.705 & 785.917 & \\
\hline 2012 & 981.115 & -21.586 & 959.529 & 981.115 & 1.210 .543 & \\
\hline 2013 & 743.669 & -17.106 & 726.563 & 743.669 & 969.007 & \\
\hline 2010 & 395.029 & -148.160 & 246.869 & 395.029 & 723.602 & \multirow{4}{*}{$\begin{array}{l}\text { AMANDO LOZA } \\
\text { ALONSO SA }\end{array}$} \\
\hline 2011 & 292.800 & -185.707 & 107.093 & 292.800 & 638.517 & \\
\hline 2012 & 327.833 & -245.872 & 81.961 & 327.833 & 519.756 & \\
\hline 2013 & 342.134 & -244.645 & 97.489 & 342.134 & 499.085 & \\
\hline 2010 & 251.402 & -82.438 & 168.964 & 251.402 & 368.323 & \multirow{4}{*}{ SALSA RICA SL } \\
\hline 2011 & 337.233 & -116.389 & 220.844 & 337.233 & 496.663 & \\
\hline 2012 & 343.698 & -96.237 & 247.461 & 343.698 & 540.603 & \\
\hline 2013 & 193.029 & -64.354 & 128.675 & 193.029 & 401.504 & \\
\hline 2010 & 149.256 & -115.885 & 33.371 & 149.256 & 519.407 & \multirow{4}{*}{$\begin{array}{l}\text { PRECOCINADOS } \\
\text { NATURALES } \\
\text { RIOJANOS SA }\end{array}$} \\
\hline 2011 & 158.425 & -149.990 & 8.435 & 158.425 & 575.390 & \\
\hline 2012 & 357.733 & -272.646 & 85.087 & 357.733 & 806.789 & \\
\hline 2013 & 92.823 & -154.570 & -61.747 & 92.823 & 516.686 & \\
\hline 2010 & 196.551 & -80.603 & 115.948 & 196.551 & 218.644 & \multirow{4}{*}{$\begin{array}{l}\text { SALSAS FINAS DE } \\
\text { RIOJA SL }\end{array}$} \\
\hline 2011 & 237.749 & -97.432 & 140.317 & 237.749 & 246.982 & \\
\hline 2012 & 238.991 & -91.839 & 147.152 & 238.991 & 248.224 & \\
\hline 2013 & 329.686 & -125.212 & 204.474 & 329.686 & 338.919 & \\
\hline 2010 & 33.920 & 8.834 & 42.754 & 33.920 & 62.856 & \multirow{4}{*}{$\begin{array}{c}\text { HARINAS } \\
\text { VAZQUEZ SA }\end{array}$} \\
\hline 2011 & 39.823 & 11.566 & 51.389 & 39.823 & 66.027 & \\
\hline 2012 & 33.888 & 14.755 & 48.643 & 33.888 & 57.208 & \\
\hline 2013 & 12.338 & 10.721 & 23.059 & 12.338 & 30.112 & \\
\hline 2010 & 31.017 & -19.606 & 11.411 & 31.017 & 106.627 & \multirow{4}{*}{$\begin{array}{l}\text { EMBUTIDOS DOMINGO } \\
\text { ORTIZ MORENO SL }\end{array}$} \\
\hline 2011 & 29.995 & -27.920 & 2.075 & 29.995 & 117.039 & \\
\hline 2012 & 37.667 & -35.316 & 2.351 & 37.667 & 127.108 & \\
\hline 2013 & 47.103 & -32.700 & 14.403 & 47.103 & 138.317 & \\
\hline
\end{tabular}




\begin{tabular}{|c|c|c|c|c|c|c|}
\hline 2010 & 109.336 & -6.772 & 102.564 & 109.336 & 185.228 & \multirow{4}{*}{$\begin{array}{c}\text { CONSERVAS CABEZON } \\
\text { SL }\end{array}$} \\
\hline 2011 & 102.632 & -12.716 & 89.916 & 102.632 & 165.576 & \\
\hline 2012 & 152.918 & -72.719 & 80.199 & 152.918 & 195.534 & \\
\hline 2013 & 106.698 & -36.269 & 70.429 & 106.698 & 135.883 & \\
\hline 2010 & 108.792 & -67.983 & 40.809 & 108.792 & 1.063 .563 & \multirow{4}{*}{$\begin{array}{c}\text { ULTRACONGELADOS } \\
\text { DEL OJA SA }\end{array}$} \\
\hline 2011 & 276.038 & -62.016 & 214.022 & 276.038 & 1.211 .770 & \\
\hline 2012 & 475.892 & -42.568 & 433.324 & 475.892 & 1.331 .157 & \\
\hline 2013 & 251.486 & -26.642 & 224.844 & 251.486 & 1.129 .474 & \\
\hline 2010 & 1.012 .423 & 59.207 & 1.071 .630 & 1.012 .423 & 1.137 .070 & \multirow{4}{*}{ PRODUMIX SA } \\
\hline 2011 & 921.213 & 224.057 & 1.145 .270 & 921.213 & 1.081 .835 & \\
\hline 2012 & 375.869 & 255.458 & 631.327 & 375.869 & 551.185 & \\
\hline 2013 & 485.537 & 520.980 & 1.006 .517 & 485.537 & 681.763 & \\
\hline 2010 & 124.394 & -35.196 & 89.198 & 124.394 & 205.167 & \multirow{4}{*}{$\begin{array}{c}\text { EMBUTIDOS SENORA } \\
\text { JULIA SL }\end{array}$} \\
\hline 2011 & -25.244 & -35.531 & -60.775 & -25.244 & 49.745 & \\
\hline 2012 & -71.396 & -33.503 & -104.899 & -71.396 & -1.603 & \\
\hline 2013 & 226.023 & -29.270 & 196.753 & 226.023 & 290.249 & \\
\hline 2010 & 165.707 & 457 & 166.164 & 165.707 & 275.009 & \multirow{4}{*}{$\begin{array}{c}\text { CONSERVAS } \\
\text { ARAMAYO SA }\end{array}$} \\
\hline 2011 & 137.462 & 8.849 & 146.311 & 137.462 & 218.463 & \\
\hline 2012 & 189.890 & 19.930 & 209.820 & 189.890 & 273.334 & \\
\hline 2013 & 192.375 & 48.902 & 241.277 & 192.375 & 271.010 & \\
\hline
\end{tabular}

\section{Indicators of profitability you:}

\begin{tabular}{|c|c|c|c|c|c|}
\hline year & $\mathbf{R e}$ & Rf & Rrc & $\mathbf{R v}$ & company \\
\hline 2010 & $10,86 \%$ & $16,63 \%$ & $8,03 \%$ & $7,44 \%$ & \multirow{4}{*}{ CONSERVAS EL CIDACOS SA } \\
\hline 2011 & $12,88 \%$ & $16,49 \%$ & $9,65 \%$ & $8,80 \%$ & \\
\hline 2012 & $7,29 \%$ & $11,60 \%$ & $6,63 \%$ & $6,23 \%$ & \\
\hline 2013 & $12,02 \%$ & $15,81 \%$ & $9,48 \%$ & $8,67 \%$ & \\
\hline 2010 & $9,87 \%$ & $37,45 \%$ & $14,98 \%$ & $13,16 \%$ & \multirow{4}{*}{$\begin{array}{c}\text { PALACIOS ALIMENTACION SAU } \\
\text { (EXTINGUA) }\end{array}$} \\
\hline 2011 & $22,00 \%$ & $54,95 \%$ & $16,72 \%$ & $14,57 \%$ & \\
\hline 2012 & $16,19 \%$ & $76,51 \%$ & $9,40 \%$ & $8,67 \%$ & \\
\hline 2013 & $13,57 \%$ & $64,49 \%$ & $8,65 \%$ & $8,05 \%$ & \\
\hline 2010 & $3,21 \%$ & $861,36 \%$ & $0,32 \%$ & $0,33 \%$ & \multirow{4}{*}{ ALEJANDRO MIGUEL SL } \\
\hline 2011 & $0,60 \%$ & $1,48 \%$ & $0,73 \%$ & $0,74 \%$ & \\
\hline 2012 & $0,83 \%$ & $1,77 \%$ & $0,65 \%$ & $0,66 \%$ & \\
\hline 2013 & $1,54 \%$ & $4,27 \%$ & $1,06 \%$ & $1,07 \%$ & \\
\hline 2010 & $-0,99 \%$ & $-2,16 \%$ & $0,24 \%$ & $0,23 \%$ & \multirow{4}{*}{ HARINERA RIOJANA } \\
\hline 2011 & $-3,85 \%$ & $-9,16 \%$ & $-0,55 \%$ & $-0,55 \%$ & \\
\hline 2012 & $1,43 \%$ & $3,34 \%$ & $1,49 \%$ & $1,47 \%$ & \\
\hline 2013 & $2,36 \%$ & $5,11 \%$ & $1,70 \%$ & $1,67 \%$ & \\
\hline 2010 & $7,38 \%$ & $54,90 \%$ & $5,13 \%$ & $4,90 \%$ & \multirow{4}{*}{ ARLUY SL } \\
\hline 2011 & $6,10 \%$ & $51,47 \%$ & $4,54 \%$ & $4,36 \%$ & \\
\hline 2012 & $5,18 \%$ & $46,87 \%$ & $4,22 \%$ & $4,07 \%$ & \\
\hline 2013 & $4,69 \%$ & $68,61 \%$ & $4,37 \%$ & $4,21 \%$ & \\
\hline 2010 & $1,79 \%$ & $86,87 \%$ & $1,35 \%$ & $1,33 \%$ & \multirow{4}{*}{$\begin{array}{c}\text { ELABORADOS NATURALES DE LA } \\
\text { RIBERA SL }\end{array}$} \\
\hline 2011 & $6,00 \%$ & $52,04 \%$ & $2,48 \%$ & $2,42 \%$ & \\
\hline 2012 & $7,81 \%$ & $41,01 \%$ & $3,22 \%$ & $3,13 \%$ & \\
\hline 2013 & $1,89 \%$ & $5,27 \%$ & $0,87 \%$ & $0,87 \%$ & \\
\hline 2010 & $-0,65 \%$ & $-1,12 \%$ & $1,04 \%$ & $1,02 \%$ & \multirow{4}{*}{ CONSERVAS FERBA SA } \\
\hline 2011 & $1,38 \%$ & $2,38 \%$ & $2,60 \%$ & $2,54 \%$ & \\
\hline 2012 & $2,24 \%$ & $4,02 \%$ & $3,66 \%$ & $3,53 \%$ & \\
\hline 2013 & $6,63 \%$ & $22,12 \%$ & $5,61 \%$ & $5,32 \%$ & \\
\hline 2010 & $16,97 \%$ & $31,75 \%$ & $12,67 \%$ & $11,26 \%$ & \multirow{4}{*}{$\begin{array}{l}\text { CONSERVAS FRANCO RIOJANA } \\
\text { SOCIEDAD ANONIMA }\end{array}$} \\
\hline 2011 & $12,15 \%$ & $20,34 \%$ & $11,14 \%$ & $10,03 \%$ & \\
\hline 2012 & $8,74 \%$ & $19,00 \%$ & $8,57 \%$ & $7,90 \%$ & \\
\hline 2013 & $6,94 \%$ & $13,18 \%$ & $8,71 \%$ & $8,03 \%$ & \\
\hline 2010 & $0,10 \%$ & $0,19 \%$ & $1,23 \%$ & $1,22 \%$ & \multirow{2}{*}{ ALBERTO DE MIGUEL SA } \\
\hline 2011 & $0,71 \%$ & $1,22 \%$ & $1,86 \%$ & $1,83 \%$ & \\
\hline
\end{tabular}




\begin{tabular}{|c|c|c|c|c|c|}
\hline 2012 & $0,60 \%$ & $1,01 \%$ & $1,83 \%$ & $1,80 \%$ & \\
\hline 2013 & $0,34 \%$ & $0,66 \%$ & $1,26 \%$ & $1,25 \%$ & \\
\hline 2010 & $5,75 \%$ & $22,76 \%$ & $3,11 \%$ & $3,03 \%$ & \multirow{4}{*}{ LA ALEGRIA RIOJANA } \\
\hline 2011 & $5,02 \%$ & $14,40 \%$ & $2,70 \%$ & $2,64 \%$ & \\
\hline 2012 & $3,88 \%$ & $13,04 \%$ & $2,03 \%$ & $2,00 \%$ & \\
\hline 2013 & $5,52 \%$ & $23,16 \%$ & $2,57 \%$ & $2,50 \%$ & \\
\hline 2010 & $19,30 \%$ & $68,76 \%$ & $16,32 \%$ & $14,11 \%$ & \multirow{4}{*}{ RIOJANA DE GRASAS SA } \\
\hline 2011 & $22,09 \%$ & $120,82 \%$ & $18,63 \%$ & $15,77 \%$ & \\
\hline 2012 & $17,51 \%$ & $156,89 \%$ & $13,93 \%$ & $12,28 \%$ & \\
\hline 2013 & $12,12 \%$ & $65,87 \%$ & $8,63 \%$ & $7,98 \%$ & \\
\hline 2010 & $4,25 \%$ & $11,66 \%$ & $3,80 \%$ & $3,67 \%$ & \multirow{4}{*}{$\begin{array}{c}\text { FONCASAL TRADING SOCIEDAD } \\
\text { LIMITADA }\end{array}$} \\
\hline 2011 & $4,68 \%$ & $13,28 \%$ & $4,18 \%$ & $4,04 \%$ & \\
\hline 2012 & $3,46 \%$ & $7,82 \%$ & $3,79 \%$ & $3,66 \%$ & \\
\hline 2013 & $-48,41 \%$ & $-123,41 \%$ & $-34,44 \%$ & $-52,62 \%$ & \\
\hline 2010 & $7,83 \%$ & $18,44 \%$ & $8,67 \%$ & $8,08 \%$ & \multirow{4}{*}{ VINAGRERIAS RIOJANAS SA } \\
\hline 2011 & $3,33 \%$ & $7,58 \%$ & $2,68 \%$ & $2,62 \%$ & \\
\hline 2012 & $2,67 \%$ & $5,45 \%$ & $2,08 \%$ & $2,05 \%$ & \\
\hline 2013 & $6,06 \%$ & $15,02 \%$ & $3,19 \%$ & $3,10 \%$ & \\
\hline 2010 & $9,16 \%$ & $12,88 \%$ & $8,42 \%$ & $7,77 \%$ & \multirow{4}{*}{$\begin{array}{l}\text { COMERCIAL RIOVERDE } \\
\text { SOCIEDAD ANONIMA }\end{array}$} \\
\hline 2011 & $7,37 \%$ & $10,69 \%$ & $6,73 \%$ & $6,31 \%$ & \\
\hline 2012 & $7,82 \%$ & $9,66 \%$ & $6,96 \%$ & $6,51 \%$ & \\
\hline 2013 & $6,69 \%$ & $9,49 \%$ & $5,55 \%$ & $5,26 \%$ & \\
\hline 2010 & $11,98 \%$ & $60,98 \%$ & $20,80 \%$ & $17,26 \%$ & \multirow{4}{*}{ EMBUTIDOS ALEJANDRO SA } \\
\hline 2011 & $8,98 \%$ & $44,34 \%$ & $21,32 \%$ & $17,64 \%$ & \\
\hline 2012 & $9,82 \%$ & $48,07 \%$ & $17,89 \%$ & $15,19 \%$ & \\
\hline 2013 & $10,21 \%$ & $51,73 \%$ & $19,39 \%$ & $16,25 \%$ & \\
\hline 2010 & $5,84 \%$ & $14,83 \%$ & $4,38 \%$ & $4,30 \%$ & \multirow{4}{*}{$\begin{array}{l}\text { GRANDERROBLE DESSERTS } \\
\text { SOCIEDAD LIMITADA }\end{array}$} \\
\hline 2011 & $14,48 \%$ & $73,57 \%$ & $10,61 \%$ & $9,74 \%$ & \\
\hline 2012 & $13,32 \%$ & $25,10 \%$ & $9,02 \%$ & $8,30 \%$ & \\
\hline 2013 & $-18,21 \%$ & $-40,71 \%$ & $-11,57 \%$ & $-13,18 \%$ & \\
\hline 2010 & $6,21 \%$ & $24,67 \%$ & $4,45 \%$ & $4,27 \%$ & \multirow{4}{*}{$\begin{array}{l}\text { MATADERO JOSE CALATAYUD E } \\
\text { HIJOS SA }\end{array}$} \\
\hline 2011 & $4,85 \%$ & $15,18 \%$ & $3,05 \%$ & $2,97 \%$ & \\
\hline 2012 & $2,54 \%$ & $6,94 \%$ & $0,91 \%$ & $0,90 \%$ & \\
\hline 2013 & $9,46 \%$ & $27,34 \%$ & $2,32 \%$ & $2,28 \%$ & \\
\hline 2010 & $7,27 \%$ & $12,36 \%$ & $5,72 \%$ & $5,43 \%$ & \multirow{4}{*}{ LACTEOS MARTINEZ SL } \\
\hline 2011 & $8,37 \%$ & $12,77 \%$ & $5,12 \%$ & $4,87 \%$ & \\
\hline 2012 & $15,40 \%$ & $23,60 \%$ & $10,06 \%$ & $9,15 \%$ & \\
\hline 2013 & $10,43 \%$ & $17,34 \%$ & $7,12 \%$ & $6,66 \%$ & \\
\hline 2010 & $2,22 \%$ & $2,58 \%$ & $4,77 \%$ & $4,59 \%$ & \multirow{4}{*}{ AMANDO LOZA ALONSO SA } \\
\hline 2011 & $0,87 \%$ & $1,01 \%$ & $3,42 \%$ & $3,31 \%$ & \\
\hline 2012 & $0,64 \%$ & $0,74 \%$ & $3,38 \%$ & $3,27 \%$ & \\
\hline 2013 & $0,73 \%$ & $0,82 \%$ & $3,17 \%$ & $3,08 \%$ & \\
\hline 2010 & $2,18 \%$ & $5,19 \%$ & $2,40 \%$ & $2,34 \%$ & \multirow{4}{*}{ SALSA RICA SL } \\
\hline 2011 & $3,04 \%$ & $8,02 \%$ & $3,21 \%$ & $3,11 \%$ & \\
\hline 2012 & $3,50 \%$ & $7,39 \%$ & $2,80 \%$ & $2,74 \%$ & \\
\hline 2013 & $2,12 \%$ & $6,38 \%$ & $1,81 \%$ & $1,78 \%$ & \\
\hline 2010 & $0,42 \%$ & $1,75 \%$ & $3,26 \%$ & $3,16 \%$ & \multirow{4}{*}{$\begin{array}{l}\text { PRECOCINADOS NATURALES } \\
\text { RIOJANOS SA }\end{array}$} \\
\hline 2011 & $0,09 \%$ & $0,59 \%$ & $4,42 \%$ & $4,74 \%$ & \\
\hline 2012 & $0,93 \%$ & $7,71 \%$ & $5,44 \%$ & $5,21 \%$ & \\
\hline 2013 & $-0,75 \%$ & $-6,90 \%$ & $1,64 \%$ & $1,62 \%$ & \\
\hline 2010 & $7,62 \%$ & $16,59 \%$ & $6,82 \%$ & $6,38 \%$ & \multirow{4}{*}{ SALSAS FINAS DE RIOJA SL } \\
\hline 2011 & $8,21 \%$ & $13,68 \%$ & $8,12 \%$ & $7,51 \%$ & \\
\hline 2012 & $7,93 \%$ & $13,30 \%$ & $7,75 \%$ & $7,19 \%$ & \\
\hline 2013 & $9,66 \%$ & $16,31 \%$ & $7,92 \%$ & $7,34 \%$ & \\
\hline 2010 & $1,90 \%$ & $2,82 \%$ & $0,84 \%$ & $0,84 \%$ & \multirow{4}{*}{ HARINAS VAZQUEZ SA } \\
\hline 2011 & $2,35 \%$ & $3,95 \%$ & $0,87 \%$ & $0,86 \%$ & \\
\hline 2012 & $2,08 \%$ & $3,18 \%$ & $0,70 \%$ & $0,70 \%$ & \\
\hline 2013 & $0,97 \%$ & $2,05 \%$ & $0,25 \%$ & $0,25 \%$ & \\
\hline 2010 & $0,55 \%$ & $5,13 \%$ & $0,73 \%$ & $0,73 \%$ & EMBUTIDOS DOMINGO ORTIZ \\
\hline
\end{tabular}




\begin{tabular}{|c|c|c|c|c|c|}
\hline 2011 & $0,10 \%$ & $0,98 \%$ & $0,72 \%$ & $0,72 \%$ & MORENO SL \\
\hline 2012 & $0,11 \%$ & $2,34 \%$ & $0,94 \%$ & $0,93 \%$ & \\
\hline 2013 & $0,70 \%$ & $13,39 \%$ & $1,06 \%$ & $1,05 \%$ & \\
\hline 2010 & $5,64 \%$ & $8,08 \%$ & $3,82 \%$ & $3,81 \%$ & \multirow{4}{*}{ CONSERVAS CABEZON SL } \\
\hline 2011 & $4,01 \%$ & $5,93 \%$ & $3,01 \%$ & $2,99 \%$ & \\
\hline 2012 & $3,26 \%$ & $3,80 \%$ & $3,76 \%$ & $3,69 \%$ & \\
\hline 2013 & $2,34 \%$ & $2,78 \%$ & $2,60 \%$ & $2,57 \%$ & \\
\hline 2010 & $0,55 \%$ & $2,13 \%$ & $3,29 \%$ & $3,19 \%$ & \multirow{4}{*}{ ULTRACONGELADOS DEL OJA SA } \\
\hline 2011 & $2,99 \%$ & $9,66 \%$ & $7,54 \%$ & $7,02 \%$ & \\
\hline 2012 & $5,86 \%$ & $19,79 \%$ & $11,62 \%$ & $10,41 \%$ & \\
\hline 2013 & $2,77 \%$ & $9,35 \%$ & $6,71 \%$ & $6,29 \%$ & \\
\hline 2010 & $14,78 \%$ & $67,45 \%$ & $34,56 \%$ & $26,15 \%$ & \multirow{4}{*}{ PRODUMIX SA } \\
\hline 2011 & $15,19 \%$ & $85,91 \%$ & $33,43 \%$ & $25,06 \%$ & \\
\hline 2012 & $7,75 \%$ & $46,18 \%$ & $11,84 \%$ & $10,59 \%$ & \\
\hline 2013 & $11,68 \%$ & $86,35 \%$ & $17,81 \%$ & $15,12 \%$ & \\
\hline 2010 & $6,18 \%$ & $16,86 \%$ & $3,88 \%$ & $3,74 \%$ & \multirow{4}{*}{ EMBUTIDOS SENORA JULIA SL } \\
\hline 2011 & $-4,71 \%$ & $-13,24 \%$ & $-0,78 \%$ & $-0,78 \%$ & \\
\hline 2012 & $-7,62 \%$ & $-24,94 \%$ & $-1,99 \%$ & $-2,03 \%$ & \\
\hline 2013 & $14,70 \%$ & $32,39 \%$ & $6,70 \%$ & $6,30 \%$ & \\
\hline 2010 & $6,26 \%$ & $38,81 \%$ & $5,94 \%$ & $5,61 \%$ & \multirow{4}{*}{ CONSERVAS ARAMAYO SA } \\
\hline 2011 & $5,37 \%$ & $156,40 \%$ & $5,43 \%$ & $5,15 \%$ & \\
\hline 2012 & $7,52 \%$ & $88,61 \%$ & $7,64 \%$ & $7,10 \%$ & \\
\hline 2013 & $7,75 \%$ & $62,03 \%$ & $6,52 \%$ & $6,12 \%$ & \\
\hline
\end{tabular}

\section{Annex 2}

\begin{tabular}{|c|c|c|c|}
\hline \multirow[b]{3}{*}{ Company Name } & \multirow{3}{*}{$\begin{array}{l}\text { Independent } \\
\text { variable } \\
\text { Net Assets } \\
\text { Turnover } \\
\text { days }\end{array}$} & \multicolumn{2}{|c|}{ Dependent variable } \\
\hline & & $\begin{array}{r}\text { Economic } \\
\text { profitability } \\
(\%) \\
\%\end{array}$ & $\begin{array}{r}\text { Economic } \\
\text { profitability } \\
(\%) \\
\%\end{array}$ \\
\hline & & Real value & $\begin{array}{r}\text { Calculated } \\
\text { value }\end{array}$ \\
\hline & 2013 & 2013 & 2013 \\
\hline Median & 1,59 & 1,07 & - \\
\hline Standard Deviation & 20,51 & 15,04 & \\
\hline Average & 4,75 & $-0,55$ & - \\
\hline SAMI $2000 \mathrm{SL}$ & 241,08 & $-149,93$ & $-137,99$ \\
\hline PANADERIA GARRIDO RIOS SL & 43,86 & $-22,58$ & $-23,29$ \\
\hline GARRIDO SANTOLAYA RAUL 000870875Z SLNE & 31,70 & 0,55 & $-16,22$ \\
\hline MANGADO-MARTINEZ SL & 30,80 & 2,67 & $-15,69$ \\
\hline PANIFICADORA CALCEATENSE SL (EN & & & \\
\hline LIQUIDACION) & 22,11 & $-5,56$ & $-10,64$ \\
\hline REGALPAN SL & 16,89 & $-3,89$ & $-7,61$ \\
\hline ELABORADOS NATURALES DE LA RIBERA & & & \\
\hline SOCIEDAD LIMITADA & 15,80 & 1,89 & $-6,97$ \\
\hline BACALAOS ALEJANDRA SOCIEDAD LIMITADA. & 15,60 & 2,73 & $-6,86$ \\
\hline CONCAL 2010 SOCIEDAD LIMITADA & 12,84 & $-1,23$ & $-5,25$ \\
\hline HARINERA RIOJANA, SA & 12,53 & 2,36 & $-5,07$ \\
\hline CARNICAS ARENZANA SL & 11,43 & 6,40 & $-4,43$ \\
\hline FRIGORIFICOS MANJARRES SA & 11,32 & 0,02 & $-4,37$ \\
\hline QUESOS CELIA SOCIEDAD LIMITADA & 10,56 & 23,24 & $-3,93$ \\
\hline GARPESA SA & 9,07 & $-29,49$ & $-3,06$ \\
\hline FRUTAS SECAS LA QUELENA SOCIEDAD & & & \\
\hline LIMITADA. & 8,36 & 1,01 & $-2,65$ \\
\hline PANADERIA ARNEDILLO SL & 7,99 & $-13,33$ & $-2,43$ \\
\hline
\end{tabular}


PANADERIA JAVIER MANGADO SL

LA ALEGRIA RIOJANA SA

EMBUTIDOS SEÑORA JULIA SL

CONSERVAS Y ENCURTIDOS ARAGON SL

ARSENIO MILLAN SL

CONSORCIO DE HARINAS SOCIEDAD LIMITADA

MATADERO COMARCAL DE ALFARO SA

NUA BIOLOGICAL INNOVATIONS SL

ALEJANDRO MIGUEL SOCIEDAD LIMITADA

GLORI Y ASCENSION SL

EMBUTIDOS DOMINGO ORTIZ MORENO SL

SOLE Y GOITA RIOJA SL

EMBUTIDOS CLAVIJO SL

POSTRES DEL CIELO SL

BALBIERO SL

ENCURTIDOS PEREZ SL

SALSAS FINAS DE RIOJA SL

PANADERIA IBAÑEZ SL

PAN CALIENTE $98 \mathrm{SL}$

PANADERIA LLORENTE S.L.

FUENTE PANADEROS SL

PANADERIAS YANGUAS SL

CONSERVAS FERBA SA

FONCASAL TRADING SOCIEDAD LIMITADA

CONSERVAS CABEZON SL

SALSA RICA SL

ENOA FOODS SA

AGROALIMENTARIOS GARU SL

HARINAS VAZQUEZ SA

EMBUTIDOS GARMAN SA

PANADERIA CAMARA S.L.

CARNICAS EMCISO SL

PANADERIA Y REPOSTERIA CONDE DE

CASALARREINA SL

HARINAS AZOFRA SL

BARRIOBERO HERMANOS SL

ARTESANA PEÑASOMO SOCIEDAD DE

RESPONSABILIDAD LIMITADA

ALBERTO DE MIGUEL SA

PANADERIA VILLAREJA S.L.

CARNICAS CAMERANAS SL

MATADERO JOSE CALATAYUD E HIJOS SA

PANADERIA EL CRUCERO SLL

PANIFICADORA SAN FELICES SA

ARLUY SL

GRANDERROBLE DESSERTS SOCIEDAD

LIMITADA.

ZUMOS UBIS SA

EMBUTIDOS GAMBOA SL

HIJOS DE ARTURO CHICOTE SL

LACTEOS MARTINEZ SL

CHAMPIÑONES AUTOL SL

H.J. HEINZ MANUFACTURING SPAIN SOCIEDAD

6

6,45

6,29
5,66

5,51

5,41

5,25

5,15

5,04

4,94

4,67

4,59

4,52

4,04

3,93

3,67

3,56

3,53

3,45

3,41

3,40

3,40

3,35

3,28

3,18

3,08

3,03
2,95

2,87

2,83

2,78

2,74

2,73

2,71

2,67

2,67

2,66

2,54

2,42

2,42

2,37

2,26

2,25

2,23

2,14

2,09

2,02

2,01

1,99

1,98

LIMITADA.

CONSERVAS EL CIDACOS SA

CONSERVAS VALERIO SL

AMANDO LOZA ALONSO SA

EMBUTIDOS ALVIC SL

TECNOCARNICO VALLE DEL EBRO, SA

LA VEGA DE QUEL SL

EMBUTIDOS BUEYO SL

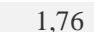

5,52

14,70

3,79

1,19

$-8,11$

$-6,16$

18,88

1,89

$-23,60$

0,70

1,76

$-1,01$

$-13,24$

0,05

1,23

9,66

1,72

12,41

$-1,28$

$-8,70$

12,30

6,63

$-48,41$

2,34

2,12

3,21

2,67

0,97

1,12

0,13

0,94

4,17

0,87

1,07

$-9,11$

0,34

0,75

$-2,94$

9,46

12,54

$-8,27$

4,69

$-1,53$
$-1,44$

$-1,08$

$-0,99$

$-0,93$

$-0,84$
$-0,78$

$-0,78$

$-0,72$

$-0,66$

$-0,50$

$-0,45$

$-0,42$

$-0,14$

$-0,07$

0,08

0,14

0,16
0,21

0,21

0,23

0,24

0,24

0,27

0,31

0,37

0,42

0,45

0,50

0,55

0,57

0,60

0,62

0,63

0,64

0,66

0,67

0,67

0,74

0,81

0,81

0,84

0,90

0,91

0,92

0,97

1,00

1,04

1,04

1,06

1,07

1,07

1,11

1,20

1,20

1,21

1,21

1,28 
RIOJANA DE GRASAS SA

EMBUTIDOS ISMAEL SL

COMERCIAL RIOVERDE SOCIEDAD ANONIMA

ALIMENTOS CONGELADOS DE LA RIOJA SA

\begin{tabular}{|c|c|c|}
\hline 1,61 & 12,12 & 1,28 \\
\hline 1,56 & 1,24 & 1,31 \\
\hline 1,49 & 6,69 & 1,35 \\
\hline 1,49 & 2,11 & 1,35 \\
\hline
\end{tabular}

ROMERO SA

CONSERVAS ARAMAYO SA

HERMANOS SAENZ DE TEJADA SL

$1,47 \quad-4,25 \quad 1,36$

EMBUTIDOS Y JAMONES G SOBRON MARTINEZ

SL

BODEGAS Y CONSERVAS LA ASUNCION SL

COOPERATIVA FRUTOS DEL CAMPO S.C.L.

LAIDIEZ ALIMENTACION SL

EMBUTIDOS BRIONES SL

EL RIOJANO SA

CONSERVAS V JALON SA

EMBUTIDOS LUIS GIL SL

CONSERVAS FRANCO RIOJANAS SOCIEDAD

ANONIMA

VEGAGEL SL

3 LISES SA

GALLETAS REYGA SL

GRUPO EMPRESARIAL PALACIOS

ALIMENTACION SA

VINAGRERIAS DEL NORTE VINANOR SL

VINAGRERIAS RIOJANAS SA

CONSERVAS MARZO SA

UCC COFFEE SPAIN SOCIEDAD LIMITADA.

PRECOCINADOS NATURALES RIOJANOS SA

EMBUTIDOS TRINI SL

L. R. 115 ALMAZARA RIOJANA S.L.

COMPAÑIA ALIMENTARIA COALA SL

CONSERVAS JUANFE SL

AJO-PEL SL

H CHICOTE PAJA Y FORRAJE SL

PASTAS SESMA SL

CHAMPIÑONES JUMA SAT

HERMANOS URUÑUELA MARTINEZ SL

SAT RUME N 8397

GRANJA EL MONTE SL

EMBUTIDOS ALEJANDRO SA

ULTRACONGELADOS DEL OJA SA

REDUCVIN SL

CONSERVAS GOMEZ AGUIRRE SL

CARNICAS DEL NAJERILLA SA

JOSE FERNANDEZ PASCUAL SOCIEDAD

ANONIMA.

KEL GRUPO ALIMENTARIO SL

MATIAS AMUTIO OLAVE SA

PANADERIA PRIMI SL

MAZAPANES DE SOTO SEGURA SA

HNOS SOBRON LOZA SL

CASA REDONDO SA

CONSERVAS SERRANO SL

ALMAZARA ECOLOGICA DE LA RIOJA SI

CONFITERIA MERINO SL

PRODUMIX SA

GRASAS INDUSTRIALES SA

LOGAR INDUSTRIAS AGROALIMENTARIAS

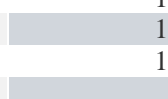

1,45

1,37

1,38

1,3

7,75

1,37

1,3

$\begin{array}{lll}1,01 & 1,41 \\ 35 & 0,20 & 1,43\end{array}$

1,43
1,44

1,47

1,49

$\begin{array}{lrr}1,16 & 2,23 & 1,54\end{array}$

\begin{tabular}{rrr}
1,16 & $-8,89$ & 1,54 \\
1,14 & 1,36 & 1,55 \\
\hline
\end{tabular}

\begin{tabular}{r|r|r|}
1,12 & 6,94 & 1,56
\end{tabular}

\begin{tabular}{lll}
1,12 & 0,47 & 1,58 \\
1,09 & 0,32 & 1,59 \\
\hline 1,07 & 9,49 & 1,59 \\
\hline
\end{tabular}

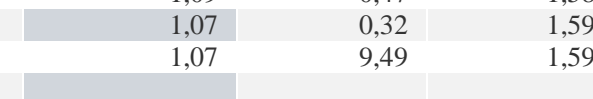

1,59

$2,13 \quad 1,61$

$\begin{array}{lrl}1,04 & 2,13 & 1,6 \\ 1,02 & -1,97 & 1,62\end{array}$

$\begin{array}{lll}0,98 & 6,06 & 1,64\end{array}$

$\begin{array}{lll}0,98 & 3,91 & 1,65\end{array}$

\begin{tabular}{lr|r}
0,95 & 5,00 & 1,66
\end{tabular}

$0,94 \quad-0,75 \quad 1,67$

$\begin{array}{lll}0,93 & 1,24 & 1,67\end{array}$

$\begin{array}{lll}0,84 & -3,51 & 1,72\end{array}$

$\begin{array}{lll}0,82 & 3,51 & 1,74\end{array}$

$\begin{array}{lll}0,77 & 6,94 & 1,77\end{array}$

$\begin{array}{lll}0,74 & 6,90 & 1,79\end{array}$

$\begin{array}{lll}0,72 & 2,83 & 1,80\end{array}$

1,80

\begin{tabular}{lr|l}
0,72 & 0,44 & 1,80 \\
0,66 & 1,19 & 1,83 \\
0,66 & $-6,07$ & 1,83
\end{tabular}

$\begin{array}{lll}0,64 & -5,08 & 1,84\end{array}$

$\begin{array}{lll}0,62 & 4,01 & 1,85\end{array}$

1,85
1,86

1,86

1,88

1,88

1,90 


\begin{tabular}{|c|c|c|c|}
\hline CONSERVAS JUKER SL. & 0,26 & $-2,72$ & 2,06 \\
\hline \multicolumn{4}{|l|}{ BODEGAS AMEZOLA DE LA MORA SOCIEDAD } \\
\hline ANONIMA & 0,26 & $-0,34$ & 2,06 \\
\hline DULCES EL AVION SA & 0,25 & $-4,36$ & 2,07 \\
\hline RICARDO LAHERA SA & 0,24 & 0,33 & 2,07 \\
\hline RIHUELO SL & 0,14 & 0,84 & 2,13 \\
\hline RIOCARTAGO S.L. & 0,13 & 15,76 & 2,14 \\
\hline ALMAZARA VALLE DEL IREGUA SL & 0,11 & 0,02 & 2,15 \\
\hline CONSERVAS CUPE S.L. & 0,11 & 2,14 & 2,15 \\
\hline CECA IMPERIAL SL & 0,07 & $-4,24$ & 2,17 \\
\hline CONSERVAS MIMO SA & 0,06 & 2,18 & 2,18 \\
\hline EXTREMIANA PALACIOS SL & 0,03 & $-9,33$ & 2,20 \\
\hline TEOFILO AZOFRA SA & 0,02 & $-1,32$ & 2,20 \\
\hline ANGEL AZOFRA SOMALO SA & 0,02 & $-0,43$ & 2,21 \\
\hline GARRAPOSA SOCIEDAD LIMITADA. & 0,02 & 1,02 & 2,21 \\
\hline HIJOS DE PABLO MARTINEZ SA & 0,01 & $-1,64$ & 2,21 \\
\hline ALEJANDRO NATURAL SL & 0,00 & $-2,04$ & 2,21 \\
\hline CONSERVAS Y VERDURAS DE LA RIOJA SL & 0,00 & $-7,46$ & 2,21 \\
\hline PIENSOS 7 CAMINOS SL. & 0,00 & $-0,16$ & 2,21 \\
\hline JAMONES ALTUZARRA SL & $-9,10$ & $-12,96$ & 7,50 \\
\hline EL HORNO DE LA CHUS SLL & $-24,53$ & $-10,65$ & 16,48 \\
\hline
\end{tabular}

